Jurnal Informatika dan Rekayasa Perangkat Lunak (JATIKA)
Vol. 2, No. 1, Maret 2021, page-page. 54 63
ISSN 2723-3367
available online at:http://jim.teknokrat.ac.id/index.php/informatika

\title{
APLIKASI MONITORING DAN PENENTUAN PERINGKAT KELAS MENGGUNAKAN NAÏVE BAYES CLASSIFIER
}

\author{
Bambang Satrio Gandhi ${ }^{1}$, Dyah Ayu Megawaty ${ }^{2}$, Debby Alita ${ }^{3}$ \\ S1 Informatika, Universitas Teknokrat Indonesial \\ S1 Sistem Informasi, Universitas Teknokrat Indonesia ${ }^{2}$ \\ S1 Informatika, Universitas Teknokrat Indonesia ${ }^{3}$ \\ dandisatrio810@gmail.com¹, aygawa02@gmail.com², debbyalita@teknokrat.ac.id ${ }^{3}$
}

Received: (date month year)Accepted: (date month year) Published: (date month year )

\begin{abstract}
Education is a benchmark in schools with good results in academic scores every semester. Academic assessment also requires tools to support academic data using technology. With the use of information technology, it can be implemented into a system that can store and manage time. So that the authors designed and developed a system that had been made before where the research carried out was the application of monitoring and class ranking using the Naïve Bayes Classifier. In addition to monitoring student semester grades, this application provides academic information, student activities, and determines the rank each student has in the class. This research uses the Extreme Programming method. The results of designing a monitoring application and class ranking using the Naïve Bayes Classifier, namely a website application. Class rank is determined using the Nä̈ve Bayes Classifier with several probabilities with an accuracy of $66.94 \%$ using Rapidminer. Tests got good results with Blackbox as functional and Iso 25010 as usability and performance testing. So it was legalized that it was feasible to be applied in monitoring students of SMAN 6 Bengkulu Selatan.
\end{abstract}

Keywords: Monitoring, academic, class rank, Nä̈ve Bayes Classifier, ISO 25010

\begin{abstract}
Abstrak
Pendidikan menjadi tolak ukur di sekolah dengan memperlihatkan hasil pencapaian nilainilai akademik pada setiap semester. Penilaian akademik juga membutuhkan alat untuk mendukung dalam mengelola data akademik dengan menggunakan teknologi. Dengan pemanfaatan teknologi informasi bisa diterapkan menjadi suatu sistem yang dapat menyimpan dan mengelola dalam waktu lama. Sehingga penulis merancang dan mengembangkan suatu sistem yang pernah dibuat sebelumnya dimana dalam penelitian yang dilakukan adalah aplikasi monitoring dan penentuan peringkat kelas menggunakan Nä̈ve Bayes Classifier. Selain memonitoring nilai-nilai semester siswa, aplikasi ini memberikan informasi akademik, galeri kegiatan kesiswaan, dan menentukan peringkat masing-masing yang dimiliki siswa dikelas. Penelitian menggunakan metode Extreme Programming. Hasil dari perancangan aplikasi monitoring dan penentuan peringkat kelas menggunakan Nä̈ve Bayes Classifier yaitu berupa aplikasi website. Peringkat kelas ditentukan menggunakan Nä̈ve Bayes Classifier dengan beberapa probabilitas dengan akurasi $66.94 \%$ menggunakan Rapidminer. Pengujian didapat dengan hasil yang baik dengan Blackbox sebagai fungsional dan ISO 25010 sebagai pengujian usability dan performance. Maka disimpulkan bahwa layak untuk diterapkan dalam memonitoring siswa SMAN 6 Bengkulu Selatan.
\end{abstract}

Kata Kunci: Monitoring, akademik, peringkat kelas, Nä̈ve Bayes Classifier, ISO 25010 
To cite this article:

Bambang Satrio Gandhi, Dyah Ayu Megawaty, Debby Alita. (2021). APLIKASI MONITORING DAN PENENTUAN PERINGKAT KELAS MENGGUNAKAN NAÏVE BAYES CLASSIFIER. Jurnal Informatika dan Rekayasa Perangkat Lunak, Vol(2) No(1), 54-63.

\section{PENDAHULUAN}

Pendidikan merupakan hal yang wajib dimiliki setiap warga negara karena sesuai dengan pasal 31 undangundang dasar 1945 yang menyatakan bahwa setiap warga negara berhak mendapatkan pendidikan dasar dan pemerintah wajib membiayainya. Menurut Surya \& Wahyu (2020), Sekolah merupakan salah satu lembaga yang menaungi pendidikan tersebut. Saat ini sekolah membutuhkan teknologi informasi, karena dengan teknologi dapat mengelola secara maksimal dan diperlukan tata kelola secara baik yang menitikberatkan pada sistem dan penggunaannya (Nugroho et al., 2016). Dengan pemanfaatan teknologi informasi bisa diterapkan menjadi sebuah kumpulan data yang saling berhubungan satu sama lain dan diorganisasikan menjadi sebuah data sistem informasi.

Saat sistem merancang suatu sistem informasi dibutuhkan informasi yang cepat dan tepat sehingga tidak dapat mempengaruhi kebijakan-kebijakan atau langkah-langkah yang dibuat (Homaidi, 2016). Informasi inilah yang dibutuhkan oleh pendidikan dalam mengelola sistem akademik maupun non-akademik.

SMAN 6 Bengkulu Selatan merupakan lembaga pendidikan yang bertugas menangani kegiatan-kegiatan yang berkaitan dengan pendidikan. Sebagai instansi pendidikan, pengelolaan data nilai rapor masih belum efisien. Disamping itu pemanfaatan teknologi masih kurang, karena salah satunya pembagian laporan pencapaian akademik siswa dilakukan secara pertemuan, setiap wali kelas dan wali siswa yang harus datang ke sekolah untuk memperoleh hasil pencapaian akademik selama satu semester (Bayu Saputra \& Cahyono, 2018). Penyampaian data akademik yang belum tepat ini memiliki informasi terbatas pada data-data tertentu seperti akademik dan kegiatan kesiswaan di sekolah sehingga wali siswa kurang lengkap dalam mendapatkan informasi kegiatan siswa dan juga dalam penyampaian data masih belum secara realtime sehingga data yang diterima wali siswa belum akurat (Hadi Prasetyo \& Kuswinardi, 2016). Selain penyampaian informasi nilai akademik dan kegiatan kesiswaan, sekolah belum menentukan pembagian masing-masing peringkat siswa dikelas. Sehingga di penelitian ini akan mencari peringkat kelas berdasarkan kriteria yang ditentukan dengan menggunakan metode Nä̈ve Bayes Classifier. Teorema ini menjadi suatu alat komponen sederhana dalam memproses klasifikasi dalam mencari nilai probabilitas tertinggi dengan tahapan yang sudah diketahui kategorinya (Alita et al., 2019).

Berdasarkan permasalahan diatas akan dibuat suatu aplikasi monitoring yang dapat menentukan peringkat kelas menggunakan Nä̈ve Bayes Classifer berbasis website sehingga dapat memberikan solusi kepada wali siswa untuk mempermudah memonitoring pencapaian akademik dan kegiatan siswa di sekolah.

\section{TELAAH PUSTAKA}

\section{Monitoring}

Monitoring adalah pemantauan perkembangan tahapan-tahapan yang telah dilalui. Monitoring juga merupakan penilaian yang terus menerus terhadap fungsi kegiatan-kegiatan proyek di dalam konteks jadwaljadwal pelaksanaan dan terhadap penggunaan input-input proyek oleh kelompok sasaran di dalam konteks harapan-harapan rancangan (Kahiril Ahsyar \& Rahman, 2018). Tujuan dari monitoring adalah melihat dan mengamati setiap kegiatan yang dilakukan dengan upaya memberikan penilaian secara bertahap sesuai konteks. Monitoring dilakukan setiap dalam kurung waktu sehingga bisa mengamati hasil yang diperoleh sebelumnya.

\section{Akademik}

Menurut Liatmaja \& Uly Wardati (2013) akademik merupakan suatu bidang yang melingkupi tentang kurikulum pembelajaran yang fungsinya untuk meningkatkan pengetahuan yang dapat dikelola oleh suatu sekolah atau Lembaga Pendidikan.

\section{Website}

Menurut Hariyanto (2017) website adalah web juga diartikan sebagai media informasi yang disatukan oleh suatu kumpulan halaman yang memuat data informasi berbentuk teks, gambar, animasi, suara, video yang bisa saling tergabung dari semuanya baik yang bersifat statis maupun dinamis dengan saling terkait oleh jaringanjaringan yang saling menghubungkan halaman/hyperlink (Setiawansyah et al., 2020).

\section{Naïve Bayes Classifier}


Teorema Naïve Bayes ini dikemukakan oleh ilmuwan Inggris bernama Thomas Bayes dengan memprediksi peluang di masa depan berdasarkan pengalaman di masa sebelumnya. Persamaan teorema Naïve Bayes yaitu:

$$
P(C \mid X)=\frac{P(x \mid c) P(c)}{P(x)}
$$

Metode yang dilakukan untuk mengukur kemiripan suatu dokumen dengan proses pengenalan teks. Nä̈ve Bayes Classifier merupakan klasifikasi yang memprediksi probabilitas suatu kelas, sehingga memiliki kelebihan tingkat akurasi yang tinggi dan waktu komputasi yang cepat (Ghaniy \& Sihotang, 2019).

\section{METODE PENELITIAN}

Proses pengembangan sistem dilakukan dengan beberapa tahapan-tahapan penelitian dari tahap identifikasi masalah dan studi literatur, analisis PIECES, perancangan UML, desain aplikasi dan pengkodean, serta evaluasi dengan melakukan pengujian sistem (Aldino \& Sulistiani, 2020). Tahapan penelitian dapat dilihat pada gambar 1.

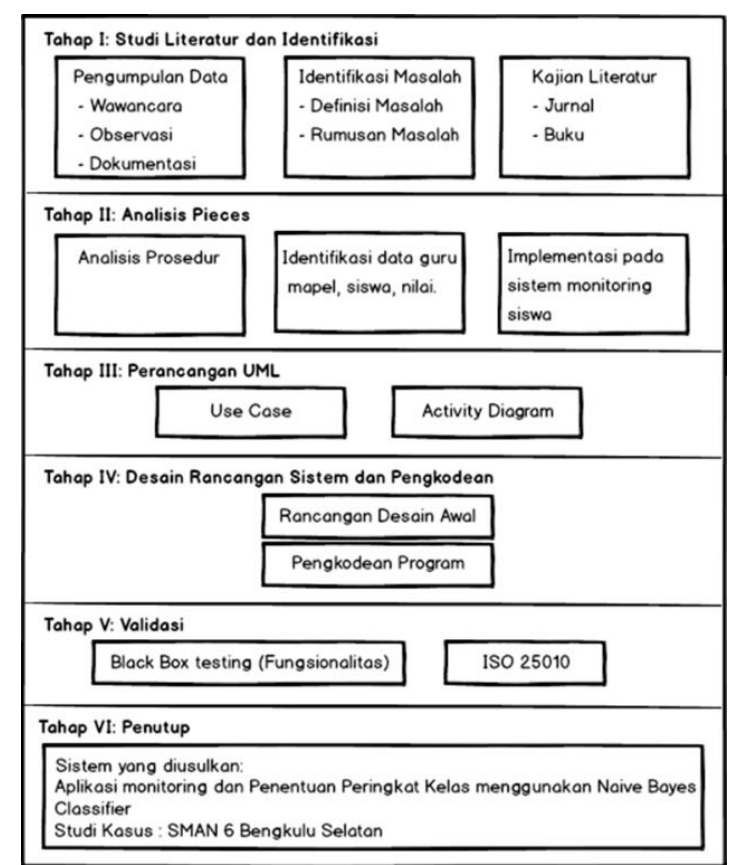

Gambar 1. Tahapan Penelitian

Dalam melakukan pengembangan sistem digunakan suatu metode Extreme Programming. Metode ini cocok dan mudah digunakan saat pengembangan karena dapat disesuaikan dengan permintaan pengguna. Metode dimulai dari perancangan dari use case dan activity diagram, desain aplikasi, pengkodean aplikasi, pengujian, dan hasil aplikasi yang dibuat (Darwis et al., 2019). 


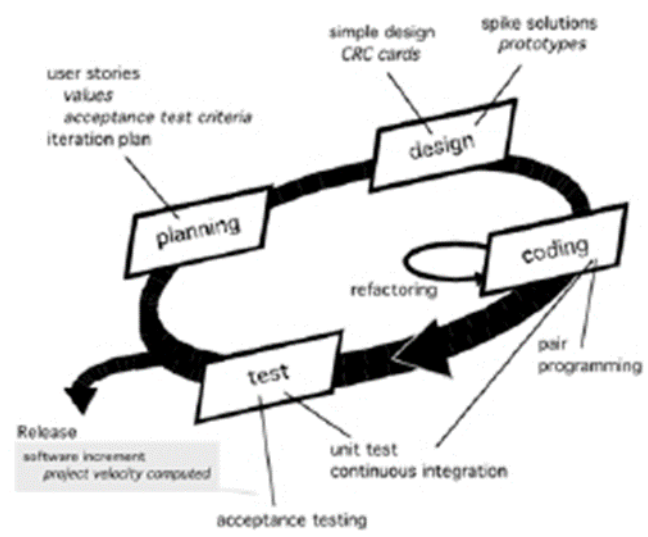

Teknik Pengumpulan Data

Gambar 2. Extreme Programming

1. Wawancara (Interview)

Wawancara merupakan suatu teknik pengumpulan data yang telah diakui sebagai data atau fakta dalam pengembangan aplikasi (Septilia et al., 2020). Wawancara dilakukan ke narasumber yang berkaitan langsung untuk menanyakan pertanyaan sebagai bahan dalam memperoleh informasi seperti data akademik, data siswa, dan alur penilaian hasil raport siswa.

2. Dokumentasi

Dokumentasi berupa data-data yang dikumpulkan seperti data siswa, data guru, data penilaian, dan data informasi sekolah.

3. Tinjauan Pustaka

Mempelajari buku atau jurnal yang berkaitan dengan penelitian sebagai bahan referensi pengembangan aplikasi agar menjadi lebih baik (Kumala et al., 2020).

\section{Metode Analisis}

Aplikasi yang dikembangkan menggunakan metode Nä̈ve Bayes Classifier saat menentukan peringkat siswa dikelas. Proses klasifikasi menjadi dua yaitu sepuluh besar dan tidak masuk. Hasil dari wawancara akan disusun dalam bentuk analisa kebutuhan fungsional (Harahap et al., 2020; Septilia et al., 2020).

\section{Variabel Operasional}

1. Variabel ekstrakurikuler

Variabel ini menentukan ikut atau tidak ekstrakurikuler pada saat data telah masuk dan akan terlihat saat menampilkan data keseluruhan.

2. Variabel rata-rata nilai pengetahuan

Variabel berasal dari jumlah nilai pengetahuan yang dibagi dengan jumlah mata pelajaran dan hasil minimal klasifikasi masuk sepuluh besar yaitu 9 keatas.

3. Variabel Absensi

Variabel ini sangat menentukan dalam proses kalsifikasi karena apabila terdapat absensi alfa tiga kali atau lebih maka tidak berhak masuk ke sepuluh besar.

\section{HASIL DAN PEMBAHASAN}

A. Planning (Perencanaan)

Kegiatan dimulai dari wawancara ke narasumber yang berkaitan. Hal ini bertujuan untuk mengumpulkan semua informasi yang dibutuhkan saat pengembangan aplikasi. Kebutuhan fungsional diperlukan saat mengetahui proses sistem saat berjalan dan siapa saja penggunanya. Berikut ini kebutuhan fungsional dari sistem:

1. Admin

a. Admin dapat melakukan login dengan menggunakan username dan password.

b. Mengelola manajemen user data guru, dan siswa seperti membuat, melihat, update, dan menghapus data. 
c. Mengelola data kelas, mata pelajaran, ekstrakurikuler, informasi kesiswaan, dan laporan nilai siswa.

2. Wali Kelas

a. Wali kelas dapat melakukan login dengan menggunakan username dan password yang disediakan oleh admin.

b. Wali kelas dapat melakukan pengisian absensi kelas Mengelola data kelas, mata pelajaran, ekstrakurikuler, informasi kesiswaan, dan laporan nilai siswa.

c. Wali kelas dapat mengisi nilai ekstrakurikuler setiap siswa.

d. Wali kelas dapat melihat seluruh data nama, nilai, peringkat siswa dikelas.

3. Guru

a. Guru dapat melakukan login dengan menggunakan username dan password yang disediakan oleh admin.

b. Guru dapat melihat mata pelajaran yang diampu.

c. Guru dapat menginput data nilai mata pelajaran yang diampu.

4. Siswa

a. Siswa dapat melakukan login dengan menggunakan username dan password yang disediakan oleh admin.

b. Orang tua/siswa dapat melihat data siswa.

c. Orang tua/siswa dapat melihat data siswa dari nilai, absen, galeri kesiswaaan, dan informasiinformasi akademik.

d. Orang tua/siswa dapat mencetak hasil nilai akhir siswa.

\section{B. Desain (Perancangan)}

Dalam pengembangan aplikasi dirancang suatu use case diagram sesuai konteks yang dibuat. Use case akan menjelaskan interaksi antara aktor dengan sistem. Use case diagram menggambarkan fungsional yang diharapkan oleh aplikasi (Budiman et al., 2019). Desain use case dapat dilihat pada gambar 2.

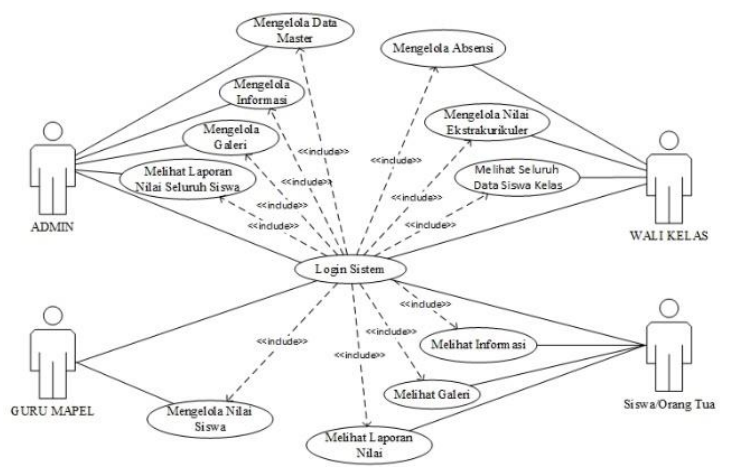

Gambar 3. Use Case Diagram

\section{Coding (Pengkodean)}

Setelah perancangan selesai, selanjutnya akan diimplementasikan kedalam bentuk kode program berupa website (Amarudin \& Sofiandri, 2018; Maulida et al., 2020). Pengkodean menggunakan bahasa html, php, javascript, dan framework laravel versi 6 menggunakan aplikasi Visual Studio Code dan database MySQL. Sesuai dengan fungsional, admin telah memasukkan data-data dari user guru, wali kelas, siswa, mata pelajaran, ekstrakurikuler, dan pengaturan kelas. Sebelum masuk ke aplikasi dapat melakukan verifikasi login terlebih dahulu. 


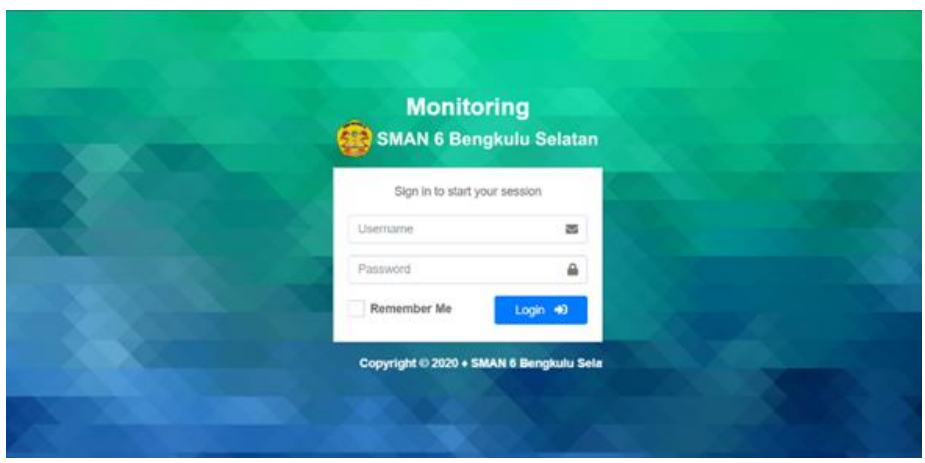

Gambar 4. Form Login Monitoring

Setelah login, akan masuk ke dashboard user masing-masing. User guru akan memiliki fitur nilai mapel dimana guru akan memasukkan nilai berdasarkan mata pelajaran kelas yang diampu. Guru akan memilih kelas dan mulai mengisi nilai sesuai kriteria ketuntasan minimal (KKM) yang sudah otomatis sesuai standar.

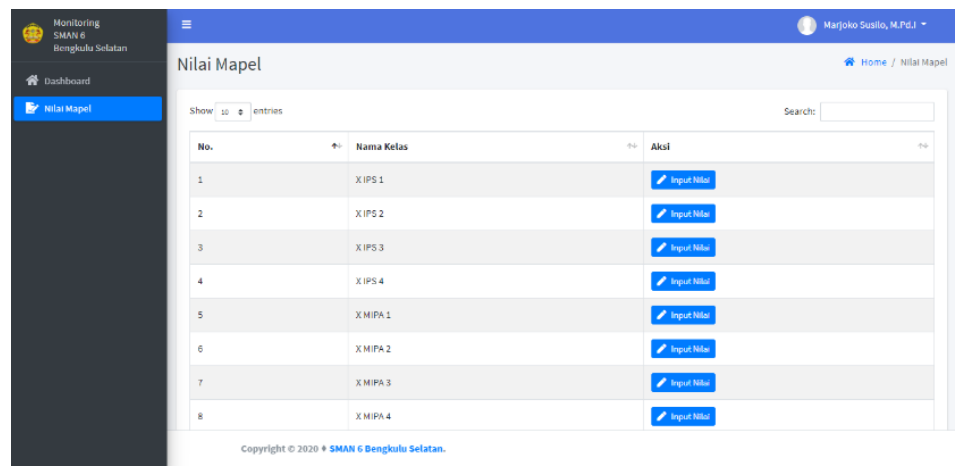

Gambar 5. Form Nilai Mapel

User wali kelas akan memiliki fitur absensi, nilai estra, dan data nilai siswa di kelas. Fitur nilai siswa menampilkan data-data siswa dari nama, jenis kelamin, ekstra, rata-rata nilai pengetahuan, absensi, dan peringkat kelas. Wali kelas dapat melihat laporan keseluruhan nilai siswa di kelasnya. Hasil Proses klasifikasi Naïve Bayes terlihat di fitur nilai ini karena semua variabel telah terpenuhi saat menentukan peringkat kelas. Untuk mengecek perhitungan dapat dilihat pada tombol Naïve Bayes diatas tabel.

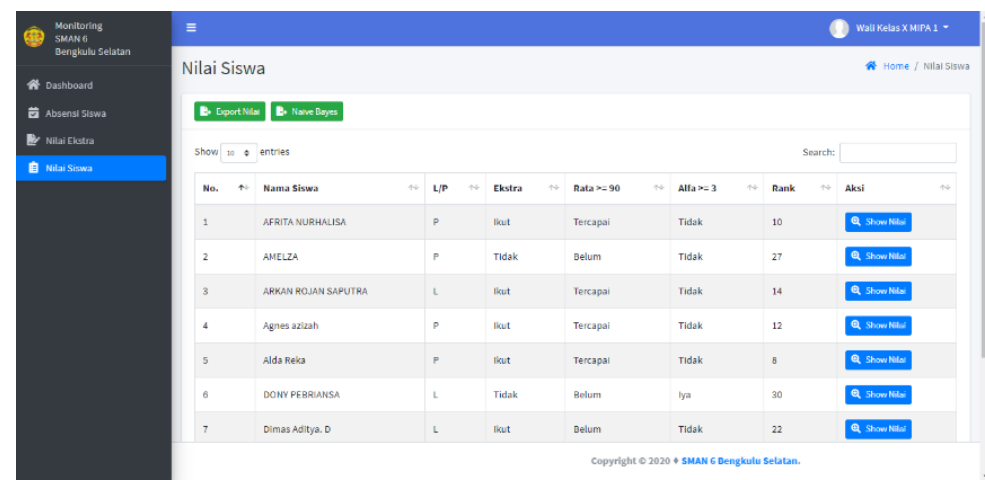

Gambar 6. Data Kelas Nilai Siswa

User siswa terdapat fitur informasi, galeri berupa foto-foto kegiatan kesiswaa, dan laporan nilai siswa per semester. Laporan nilai akan menampilkan keseluruhan nilai mata pelajaran, absensi, dan ekstrakurikuler. Laporan dapat juga dicetak secara lengkap untuk melihat nilai berupa angka. 


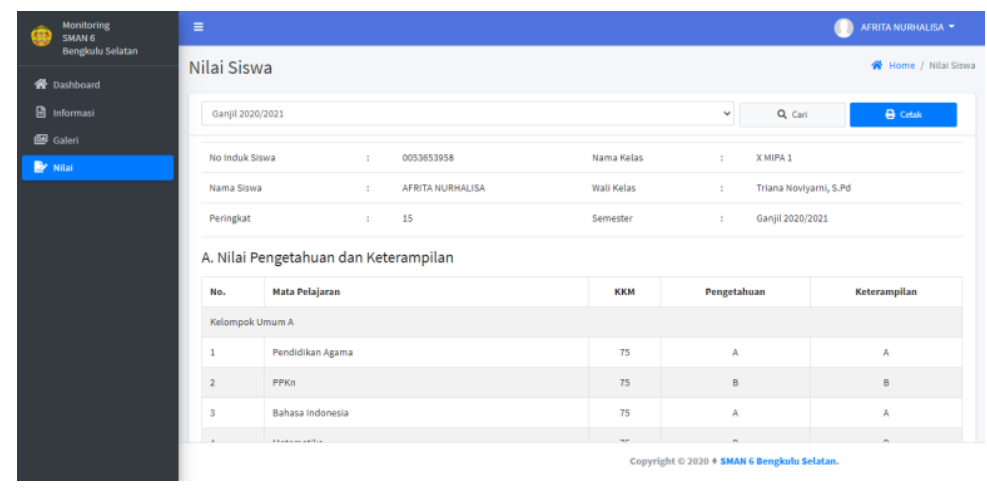

Gambar 7. Laporan Nilai Siswa

D. Klasifikasi Nä̈ve Bayes

Implementasi perhitungan ini digunakan pada perbandingan klasifikasi peringkat siswa didalam suatu kelas. Klasifikasi ditentukan pertama kali untuk mengelompokkan sepuluh besar dan tidak masuk sepuluh besar. Kriteria-kriteria penentunya dari rata-rata nilai pengetahuan, ikut ekstrakurikuler atau tidak, dan absensi kehadiran. Untuk menentukan semua hasil klasifikasi Naïve Bayes di semua peringkat kelas, maka terdapat dokumen training dan dokumen testing.

1. Dokumen Training

Dokumen ini sebagai acuan dalam proses testing yang ditentukan oleh kriteria-kriteria dari ratarata nilai pengetahuan lebih dari sembilan, banyak yang ikut ekstra atau tidak, dan absensi alfa yang lebih dari tiga kali maka tidak bisa masuk sepuluh besar. Dokumen training ini mempunyai jumlah 32 data.

2. Dokumen Testing

Dalam penelitian yang dilakukan, jenis dokumen ini didapat dari data informasi dalam aplikasi monitoring. Dokumen ini akan digunakan sebagai proses testing terhadap dokumen training. Dokumen testing ini mengambil seluruh siswa yang berjumlah 732 dan kriteria yang diperlukan yang telah digabung menjadi satu dari seluruh kelas agar diuji keakuratan perhitungan Naïve Bayes ini. Dokumen tetsing ini merupakan gabungan dari semua kelas untuk diuji coba keseluruhan klasifikasi.

\section{Sampel Klasifikasi}

Proses klasifikasi dokumen membutuhkan perhitungan setiap dokumen testing yang diuji ke dokumen training. Dokumen testing dilakukan perhitungan Naïve Bayes setiap kelas yang diambil dua kelompok yaitu sepuluh besar dan tidak masuk. Sepuluh besar akan dilihat jumlah ikut atau tidak, rata-rata nilai, dan alfa lebih dari tiga kali atau tidak, jika iya maka tidak berhak masuk ke sepuluh besar. Sebagai contoh dapat dilihat beberapa data dokumen testing yang terdiri 31 orang di suatu kelas.

Tabel 1. Sampel Dokumen Testing

\begin{tabular}{|l|l|c|c|c|c|}
\hline $\begin{array}{l}\text { Ekstrak } \\
\text { urikuler }\end{array}$ & $\begin{array}{c}\text { Rata-rata nilai } \\
\text { (Total/jmlMapel) }>=90\end{array}$ & $\begin{array}{c}\text { Alpa } \\
\mathbf{>}=\mathbf{3}\end{array}$ & $\mathbf{1 0}$ Besar & $\begin{array}{c}\text { Tidak } \\
\text { Masuk }\end{array}$ & $\begin{array}{c}\text { Class } \\
\text { Prediction }\end{array}$ \\
\hline Tidak & Tercapai & Tidak & 0,225806452 & 0,5529953 & Tidak Masuk \\
& Tercapai & Iya & 0 & 92 & \\
\hline Ikut & Tercapai & & & 0,0276497 & Tidak Masuk \\
& & Tidak & 0,096774194 & 0,0921658 & 10 Besar \\
\hline
\end{tabular}




\begin{tabular}{|l|l|l|l|l|l|}
\hline Ikut & Tercapai & Tidak & 0,096774194 & 0,0921658 & 10 Besar \\
\hline Tidak & Tercapai & Tidak & 0,225806452 & 0,5529953 & Tidak Masuk \\
& & & & 92 & \\
\hline
\end{tabular}

Perhitungan didapatkan dari metode Naïve Bayes, dimana probabilitas prior didapat dari pembagian kelompok sepuluh besar dan tidak masuk dibagi dengan jumlah siswa di kelas. Kemudian dilakukan perhitungan probabilitas posterior bersyarat berdasarkan jumlah kriteria yang ada pada kelompok sepuluh besar dan tidak masuk dan dikali probabilitas prior. Jika hasil nilai kelompok sepuluh besar lebih tinggi daripada kelompok tidak masuk maka termasuk sebagai sepuluh besar dan sebaliknya. Probabilitas sangat berpengaruh pada masing-masing siswa untuk menentukan peringkat, seperti banyaknya yang ikut ekstrakurikuler atau juga pengaruh absen jika alfa 3 kali maka tidak boleh masuk ke sepuluh besar. Perhitungan klasifikasi Naïve Bayes inilah yang diimplementasikan ke aplikasi, dimana menentukan siswa yang berhak masuk ke sepuluh besar dan peringkat kelas akan otomatis mengurutkan.

4. Akurasi

Pada penelitian implementasi Naïve Bayes yang dilakukan menggunakan aplikasi Rapidminer Studio dengan dokumen testing sebanyak 732 dokumen yang mengacu pada 32 data training yang sudah ada dan menghasilkan $66.94 \%$.

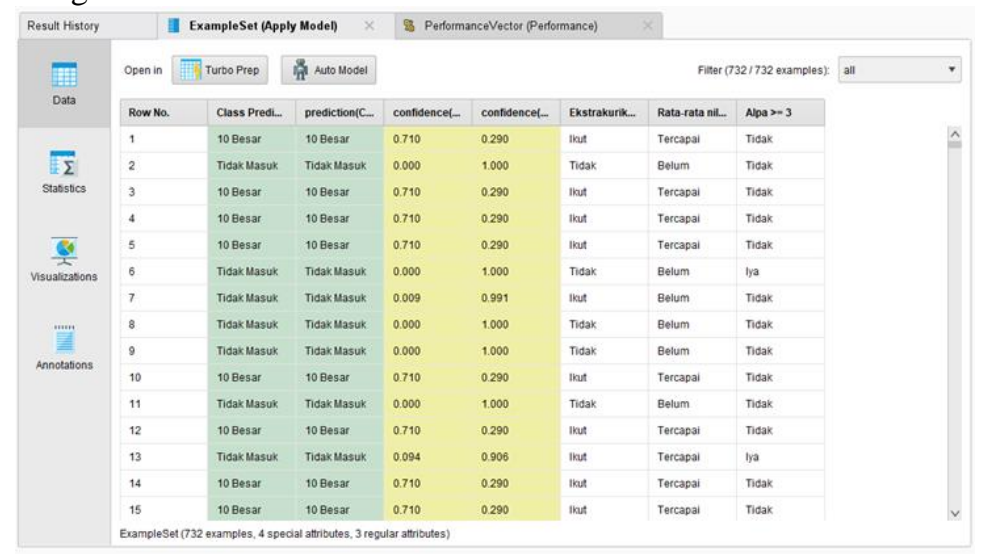

Gambar 8. Data Akurasi Rapidminer

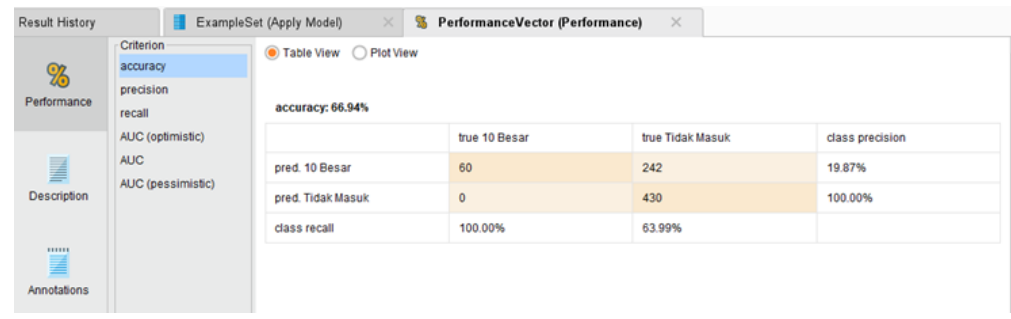

Gambar 9. Hasil Akurasi

\section{E. Testing (Pengujian)}

Sebelum aplikasi dapat digunakan ke sekolah, dilakukan pengujian menggunakan dua metode yaitu Blacbox untuk fungsional dan ISO 25010 untuk usability (Ahdan \& Setiawansyah, 2020). Pengujian blackbox akan dites fungsi fitur masing-masing user apakah berjalan sesuai fungsional atau tidak dengan melibatkan 16 responden dan hasil pengujian mendapatkan sebesar $100 \%$. 
Pengujian usability pada ISO 25010 melibatkan 15 responden dengan 10 butir pertanyaan. Kuesioner dibuat dengan menggunakan skala likert. Berikut hasil dari pengujian usability testing.

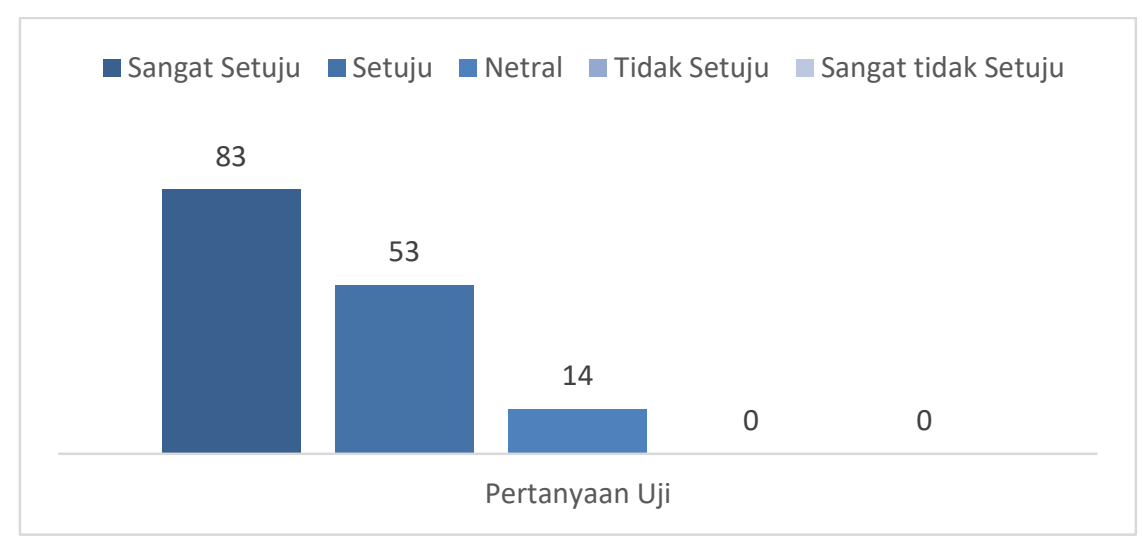

Gambar 10. Hasil Pengujian Usability

Dari hasil pengujian usability menunjukkan hasil nilai $89.2 \%$ menggunakan skala likert sehingga dapat disimpulkan penyesuaian skala nilai yang diperoleh dari 81-100 sangat tinggi atau mudah digunakan.

\section{SIMPULAN}

Berdasarkan hasil dari pembuatan dan pengujian aplikasi, maka dapat disimpulkan sebagai berikut:

1. Aplikasi monitoring dan penentuan peringkat kelas menggunakan Naïve Bayes Classifier dapat mengelola fungsi masing-masing user dengan sangat baik.

2. Penerapan Naïve Bayes Classifier telah berhasil menerapkan implementasi Naïve Bayes pada peringkat siswa dengan menyeleksi kriteria-kriteria yang dibutuhkan dalam klasifikasi Naïve Bayes dengan akurasi $66.94 \%$ dari 732 data testing siswa menggunakan aplikasi Rapidminer.

3. Pada pengujian aplikasi menggunakan blackbox telah didapatkan nilai $100 \%$ dari 16 responden untuk menguji fungsi fitur aplikasi setiap user. Dalam aspek usability, pengujian didapatkan nilai $89.2 \%$ sehingga aplikasi memiliki hasil uji kegunaan yang sangat tinggi atau mudah untuk digunakan.

\section{UCAPAN TERIMA KASIH}

Puji syukur penulis panjatkan doa kepada Tuhan YME, karena atas berkat dan rahmat-Nya, penulis dapat menyelesaikan penelitian dengan judul "Aplikasi Monitoring dan Penentuan Peringkat Kelas Menggunakan Naïve Bayes Classifier". Penulis juga mengucapkan terima kasih kepada:

1. Dr.H.M. Nasrullah Yusuf, S.E., M.BA. selaku Rektor Universitas Teknokrat Indonesia.

2. Dr.H. Mahathir Muhammad, S.E., M.M. selaku Dekan Fakultas Teknik dan Ilmu Komputer

3. Ibu Dyah Ayu Megawaty, M. Kom. selaku Ketua Program Studi S1 Informatika Fakultas Teknik dan Ilmu Komputer Universitas Teknokrat Indonesia.

\section{REFERENSI/DAFTAR PUSTAKA}

Ahdan, S., \& Setiawansyah, S. (2020). Pengembangan Sistem Informasi Geografis Untuk Pendonor Darah Tetap di Bandar Lampung dengan Algoritma Dijkstra berbasis Android. Jurnal Sains Dan Informatika: Research of Science and Informatic, 6(2), 67-77.

Aldino, A. A., \& Sulistiani, H. (2020). DECISION TREE C4. 5 ALGORITHM FOR TUITION AID GRANT PROGRAM CLASSIFICATION (CASE STUDY: DEPARTMENT OF INFORMATION SYSTEM, UNIVERSITAS TEKNOKRAT INDONESIA). Edutic-Scientific Journal of Informatics Education, 7(1).

Alita, D., Priyanta, S., \& Rokhman, N. (2019). Analysis of Emoticon and Sarcasm Effect on Sentiment Analysis of Indonesian Language on Twitter. Journal of Information Systems Engineering and Business Intelligence, 5(2), 100.

Amarudin, A., \& Sofiandri, A. (2018). Perancangan dan Implementasi Aplikasi Ikhtisar Kas Masjid Istiqomah Berbasis Desktop. Jurnal Tekno Kompak, 12(2), 51-56. 
Bayu Saputra, A., \& Cahyono, A. (2018). Aplikasi Monitoring Capaian Kompetensi Peserta Didik di SMA Kolombo Yogyakarta. Ilmiah Bidang Teknologi, X, 172-179.

Budiman, A., Wahyuni, L. S., \& Bantun, S. (2019). Perancangan Sistem Informasi Pencarian Dan Pemesanan Rumah Kos Berbasis Web (Studi Kasus: Kota Bandar Lampung). Jurnal Tekno Kompak, 13(2), 24-30.

Darwis, D., Pasaribu, A. F., \& Surahman, A. (2019). Sistem Pencarian Lokasi Bengkel Mobil Resmi Menggunakan Teknik Pengolahan Suara dan Pemrosesan Bahasa Alami. Jurnal Teknoinfo, 13(2), 71-77.

Ghaniy, R., \& Sihotang, K. (2019). Penerapan Metode Naïve Bayes Classifier Untuk Penentuan Topik Tugas Akhir. Teknois : Jurnal Ilmiah Teknologi Informasi Dan Sains, 9(1), 63-72.

Hadi Prasetyo, I., \& Kuswinardi, W. (2016). Pengembangan Sistem Informasi Monitoring Akademik Siswa Sekolah Menengah Atas Negeri ( SMAN ) Di Kota Malang. Journal Of Information System and Technology Information and Communication, 1(November 2018), 31-45.

Hariyanto, A. (2017). Membuat Aplikasi Computer Based Test dengan PHP, MySQLi dan Bootstrap (L. Hakim (ed.)). Lokomedia.

Harahap, A., Sucipto, A., \& Jupriyadi, J. (2020). PEMANFAATAN AUGMENTED REALITY (AR) PADA MEDIA PEMBELAJARAN PENGENALAN KOMPONEN ELEKTRONIKA BERBASIS ANDROID. Jurnal Ilmiah Infrastruktur Teknologi Informasi, 1(1), 20-25.

Homaidi, A. (2016). Sistem Informasi Akademik AMIK IBRAHIMY Berbasis WEB. Jurnal Ilmiah Informatika, $1,17-23$.

Irawan, A., Rohaniah, R., Sulistiani, H., \& Priandika, A. T. (2019). Sistem Pendukung Keputusan Untuk Pemilihan Tempat Servis Komputer di Kota Bandar Lampung Menggunakan Metode AHP. Jurnal Tekno Kompak, $13(1), 30$.

Kahiril Ahsyar, T., \& Rahman, A. (2018). SISTEM MONITORING PIUTANG DAN INVENTORI BARANG. Ilmiah Rekayasa Dan Manajemen Sistem Informasi, 4(2).

Kumala, N. K. R., Puspaningrum, A. S., \& Setiawansyah, S. (2020). E-DELIVERY MAKANAN BERBASIS MOBILE (STUDI KASUS: OKONOMIX KEDATON BANDAR LAMPUNG). Jurnal Teknologi Dan Sistem Informasi, 1(2), 105-110.

Liatmaja, R., \& Uly Wardati, I. (2013). SISTEM INFORMASI AKADEMIK BERBASIS WEB PADA LEMBAGA BIMBINGAN BELAJAR BE EXCELLENT PACITAN Rizka Liatmaja, Indah Uly Wardati. Indonesian Jurnal on Networking and Security (IJNS), 2, 58-63.

Megawaty, D. A., Setiawansyah, Bakri, M., \& Damayanti, E. (2020). Sistem Monitoring Kegiatan Akademik Siswa. TEKNOKOMPAK, 14(2), 98-101.

Maulida, S., Hamidy, F., \& Wahyudi, A. D. (2020). Monitoring Aplikasi Menggunakan Dashboard Untuk Sistem Informasi Akuntansi Pembelian Dan Penjualan. Jurnal TEKNO KOMPAK, 14(1), 47-53.

Septilia, H. A., Parjito, P., \& Styawati, S. (2020). SISTEM PENDUKUNG KEPUTUSAN PEMBERIAN DANA BANTUAN MENGGUNAKAN METODE AHP. Jurnal Teknologi Dan Sistem Informasi, 1(2), 34-41.

Setiawansyah, S., Sulistiani, H., \& Saputra, V. H. (2020). Penerapan Codeigniter Dalam Pengembangan Sistem Pembelajaran Dalam Jaringan Di SMK 7 Bandar Lampung. Jurnal CoreIT: Jurnal Hasil Penelitian Ilmu Komputer Dan Teknologi Informasi, 6(2), 89-95.

Suaidah, S. (2018). Perancangan Monitoring Prestasi Akademik Dan Aktivitas Siswa Menggunakan Pendekatan Key Performance Indicator (Studi Kasus Sma N 1 Kalirejo). Jurnal Tekno Kompak, 12(2), 62.

Surya, C., \& Wahyu, A. (2020). SISTEM INFORMASI PERHITUNGAN POIN PELANGGARAN SISWA MENGGUNAKAN METODE SIMPLE ADDITIVE WEIGHTING (SAW) (Studi Kasus Di SMK As-Shofa Kabupaten Tasikmalaya). Jurnal Teknoinfo, 14(1), 59.

Wantoro, A. (2018). Prototype Aplikasi Berbasis Web Sebagai Media Informasi Kehilangan Barang. Jurnal Teknoinfo, 12(1), 11. 